\title{
Incidence of inflammatory bowel disease in north west Greece: rarity of Crohn's disease in an area where ulcerative colitis is common
}

\author{
E V Tsianos, C N Masalas, M Merkouropoulos, G N Dalekos, R F A Logan
}

\begin{abstract}
Ulcerative colitis (UC) and Crohn's disease (CD) are generally regarded as diseases of affluent societies of the Western World, although their frequency in less affluent areas is not well established. This retrospective study therefore, assesses the incidence of UC and $C D$ in a semirural area of north west Greece during the 10 year period 1982-1991. By the 31 December 1991, 61 patients had met standard diagnostic criteria for UC (annual incidence $4 \cdot 0 / 10^{5}, 95 \%$ confidence intervals $3 \cdot 0$ to $5 \cdot 0 / 10^{5}$ ) and only five patients met the diagnostic criteria for $C D$ (annual incidence $0 \cdot 3 / 10^{5}, 95 \%$ confidence intervals $0 \cdot 1$ to $0 \cdot 8 / 10^{5}$ ) in this area of 157214 inhabitants. UC incidence was lowest in the first three years at $1 \cdot 8 / 10^{5}$ per annum and subsequently increased to 4.8 and $5 \cdot 1 / 10^{5}$ per annum for the successive four and three year periods respectively. UC incidence was slightly higher in men. A third of all cases of UC had pancolitis while a quarter had only proctitis. More than one half were categorised as having moderate or severe colitis. Three quarters of the patients resided in urban areas. The incidence of CD was a twelfth of the UC incidence, which is in considerable contrast with most Western countries where the incidence of $\mathrm{CD}$ is usually no less than a third that for UC. The rarity of CD points to the absence of aetiological environmental factors specific for $\mathrm{CD}$.

(Gut 1994; 35: 369-372)
\end{abstract}

Epidemiological studies of inflammatory bowel disease have generally found the incidence to be highest in north west Europe especially in the United Kingdom ${ }^{1}$ and in Scandinavia. ${ }^{23}$ Although the frequency of inflammatory bowel disease in south and eastern Europe is not well

Department of Internal Medicine (Hepato-

Gastroenterology

Division), School of

Medicine, University of

Ioannina, Greece

E V Tsianos

C N Masalas

M Merkouropoulos

G N Dalekos

Department of Public

Health and

Epidemiology, Queen's

Medical Centre,

Nottingham

R F A Logan

Correspondence to:

DrV Tsianos, Chief, Hepato-

Gastroenterology Division,

Department of Internal

Medicine, University of

Ioannina, PO Box 1186

45110 Ioannina, Greece.

Accepted for publication

7 July 1993 north west Greece established there have been reports of a low incidence. ${ }^{45}$

In this retrospective study we have assessed the incidence of UC and CD in the Ioannina prefecture - a semirural area of north west Greece, during the years from June 1982 to December 1991.

\section{Area and methods}

Ioannina is one of the four prefectures of Epirus county, which is an extremely isolated and semirural area of north west Greece. The total population, according to the 1991 census (National Statistic Organisation) is 157214 residents, which represents a seven per cent increase since the 1981 census (147 139). Table I shows the population structure according to the 1981 census.

The health care system is of mixed type including both a National Health Service and a private sector. The National Health Service consists of five health centres staffed by 56 general practitioners and two general hospitals with about 1000 beds, staffed by specialists. One of the hospitals (opened in 1991), is now the research and teaching hospital of the University of Ioannina whose medical school started in 1977. The other hospital is a general hospital of the National Health Service and until 1990 served as the university hospital. There are no hospitals in the private sector. For the last four years there have been two gastroenterologists and two fellows in gastroenterology in the area. There are no private gastroenterologists working in the area. All endoscopic procedures including colonoscopy are performed in the hospital endoscopy units. Finally, there is a university department of radiology started in 1980.

This study is based on a retrospective search of records and pathology from the archives of our

TABLE I Age specific incidence rates (per 100000 inhabitants) of ulcerative colitis ( $n=61$ ) in Ioannina prefecture,

\begin{tabular}{|c|c|c|c|c|c|c|c|c|c|c|}
\hline Age & No & Men & No & Women & No & $\begin{array}{l}\text { Both } \\
\text { sexes }\end{array}$ & Men & Women & $\begin{array}{l}\text { Both } \\
\text { sexes }\end{array}$ & $\begin{array}{l}95 \% \text { Confidential } \\
\text { intervals }\end{array}$ \\
\hline $\begin{array}{l}0-24 \\
15-24 \\
25-34 \\
35-44 \\
45-54 \\
55-64 \\
65-74 \\
>75\end{array}$ & $\begin{array}{l}0 \\
4 \\
3 \\
9 \\
4 \\
7 \\
5 \\
2\end{array}$ & $\begin{array}{l}(17749)^{\star} \\
(11186) \\
(9181) \\
(8470) \\
(9218) \\
(6772) \\
(6431) \\
(3297)\end{array}$ & $\begin{array}{l}0 \\
8 \\
4 \\
6 \\
6 \\
2 \\
1 \\
0\end{array}$ & $\begin{array}{c}(16457) \\
(10715) \\
(9423) \\
(8224) \\
(10193) \\
(7891) \\
(7350) \\
(4551)\end{array}$ & $\begin{array}{r}0 \\
12 \\
7 \\
15 \\
10 \\
9 \\
6 \\
2\end{array}$ & $\begin{array}{l}(34206) \\
(21901) \\
(18604) \\
(16694) \\
(19411) \\
(14663) \\
(13781) \\
(7848)\end{array}$ & $\begin{array}{r}- \\
3 \cdot 5 \\
3 \cdot 2 \\
10 \cdot 3 \\
4 \cdot 2 \\
10 \cdot 0 \\
7 \cdot 5 \\
5 \cdot 9\end{array}$ & $\begin{array}{l}-7 \cdot 2 \\
4 \cdot 1 \\
7 \cdot 1 \\
5 \cdot 7 \\
2 \cdot 5 \\
1 \cdot 3 \\
-\end{array}$ & $\begin{array}{l}- \\
5 \cdot 3 \\
3 \cdot 6 \\
8 \cdot 7 \\
5 \cdot 0 \\
5 \cdot 9 \\
4 \cdot 2 \\
2 \cdot 5\end{array}$ & $\begin{array}{l}-\overline{(2.7} \text { to } 9 \cdot 2) \\
(1.5 \text { to } 7 \cdot 5) \\
(4.9 \text { to } 14 \cdot 3) \\
(2.4 \text { to } 9 \cdot 2) \\
(2.7 \text { to } 11 \cdot 3) \\
(1.5 \text { to } 9 \cdot 2) \\
(0.3 \text { to } 8 \cdot 9)\end{array}$ \\
\hline $\begin{array}{l}\text { Total/ } \\
\text { Mean }\end{array}$ & 34 & (72 304) & 27 & (74 804) & 61 & $\left(\begin{array}{l}147 \\
108\end{array}\right)$ & $4 \cdot 6$ & $3 \cdot 5$ & $4 \cdot 0$ & $(3.0$ to 5.0$)$ \\
\hline
\end{tabular}

$\star$ Numbers in brackets represent population distribution (sex and age breakdown) in Ioannina prefecture in 1981, incidence calculated using 1981 population $\times 1.035$ to give estimated mid period population. 
TABLE II Inclusion criteria for ulcerative colitis and Crohn's disease

\begin{tabular}{|c|c|c|}
\hline & Ulcerative colitis & Crohn's disease \\
\hline History & $\begin{array}{l}\text { Patients with diarrhoea or rectal } \\
\text { bleeding, or both for more than } 2 \\
\text { weeks or repeated episodes }\end{array}$ & $\begin{array}{l}\text { Patients with diarrhoea or rectal } \\
\text { bleeding, or both and weight loss } \\
\text { for more than } 4 \text { weeks, or } \\
\text { repeated episodes }\end{array}$ \\
\hline Laboratory tests & Exclusion of infectious diseases & Exclusion of infectious diseases \\
\hline Radiological signs & $\begin{array}{l}\text { Ulcerations with or without } \\
\text { spiculated granulated inner surface } \\
\text { of the rectum or colon, or both }\end{array}$ & $\begin{array}{l}\text { Stenoses and prestenotic } \\
\text { dilatations in the small or large } \\
\text { bowel, segmental findings, } \\
\text { burrowing ulcerations, strictures } \\
\text { or the formation of fistulas }\end{array}$ \\
\hline Endoscopy & $\begin{array}{l}\text { Typical sigmoidoscopic or } \\
\text { colonoscopic picture with } \\
\text { granulated, friable mucosa or } \\
\text { ulcerations or both, of the surface } \\
\text { mucosa }\end{array}$ & $\begin{array}{l}\text { 'Cobblestone' appearance of } \\
\text { affected segments of the bowel or } \\
\text { aphthoid ulcers, or both }\end{array}$ \\
\hline Histology & $\begin{array}{l}\text { Inflammatory changes indicative of } \\
\text { ulcerative colitis }\end{array}$ & $\begin{array}{l}\text { Signs of inflammatory changes } \\
\text { indicative of Crohn's disease or } \\
\text { epithelial granulomata, or both }\end{array}$ \\
\hline
\end{tabular}

division of hepatogastroenterology. Only cases that met the diagnostic criteria (Table II) at least twice in a time span of six months or more were included in this study.

For patients with UC the extent as determined by radiology and colonoscopy in patients with UC was recorded at the time of maximal colonic involvement: (1) pancolitis (entire colon affected or involvement proximal to the transverse colon); (2) left colitis (no involvement proximal to the splenic flexure); and (3) proctitis (no involvement proximal to the rectum or the first $15 \mathrm{~cm}$ ).

The severity of UC was classified according to the criteria of Truelove and Witts. ${ }^{6}$

Mild - diarrhoea with four or fewer motions/ day and only small amounts of macroscopic blood in the stools, no fever; no tachycardia; not severe anaemia; and an erythrocyte sedimentation rate less than $30 \mathrm{~mm} / \mathrm{h}$.

Severe - diarrhoea with six or more motions/ day with macroscopic blood in the stools; either a mean evening temperature above $37.5^{\circ} \mathrm{C}$ or a temperature of $37 \cdot 7^{\circ} \mathrm{C}$ or more on at least two days out of four; tachycardia with a mean pulse rate of more than $90 / \mathrm{min}$; anaemia with a packed cell volume $34 \%$ or less; and an erythrocyte sedimentation rate greater than $30 \mathrm{~mm} / \mathrm{h}$.

Moderate - anything between mild and severe.

All these patients (UC and CD) were living in the Ioannina prefecture, Greece and had attended our hepatogastroenterology clinic. They were registered according to: age, sex, area of residence, extent and severity of the disease, presence of constipation (<three defecations/ week), extraintestinal manifestations, and year of diagnosis.

The date of diagnosis was used to date incidence. For calculation of age and sex specific incidence an estimated mid period population was calculated by multiplying the 1981 population figures (Table I) by $3 \cdot 5 \%$ (half the total increase in population during the 10 years). For calculation of incidence for the periods 1985-88 the same mid period estimate was used and for 1989-91 the 1991 census figures were used. The prevalence was calculated as of December 1991.

\section{STATISTICAL ANALYSIS}

Ninety five per cent confidence intervals (CI) were obtained using either the confidence interval analysis programme ${ }^{7}$ or an exact method based on the Poisson distribution when the number of cases was less than 20 .

\section{Results}

By the 31 December 1991, assessment was made of the total number of patients with UC and CD, who resided in Ioannina prefecture, Greece. There were 61 patients who met the diagnostic criteria of UC ( 34 male, 27 female, male/female ratio of 1.25 ) and five patients (three male, two female) with CD (Tables III and IV). Twelve cases had been diagnosed elsewhere, before June 1982 and have been followed up since then at the outpatient hepatogastroenterology clinic. The total number of UC patients who are followed up at our clinic today is 165 patients, and the total number of $\mathrm{CD}$ is 14 patients.

The Figure and Table I show the year of diagnosis and age distribution at the time of diagnosis for the 61 patients with UC as well as the age specific incidence rates. Peak occurrence was between $35-44$ years of age. The highest age specific incidence rate was $8 \cdot 7 / 100000$ inhabitants for patients between $35-44$ year of age. The highest rate for men was $10 \cdot 3 / 100000$ inhabitants and for women was $7 \cdot 1 / 100000$ inhabitants between 35-44 years of age. Table III shows the annual incidence rates for UC patients. The mean annual incidence rate was $4 \cdot 0 / 100000$ inhabitants for the entire group $(95 \% \mathrm{CI} 3.0$ to $\left.5 \cdot 0 / 10^{5}\right)$. The annual incidence rate was lowest in the first three years at $1 \cdot 8 / 10^{5}$ per annum and subsequently increased to $4 \cdot 8$ and $5 \cdot 1 / 10^{5}$ per annum for the successive four and three year

TABLE III Annual incidence rates of ulcerative colitis per 100000 with $95 \%$ confidence intervals

\begin{tabular}{|c|c|c|c|c|c|c|}
\hline \multirow{2}{*}{$\begin{array}{l}\text { Year of } \\
\text { the study }\end{array}$} & \multicolumn{2}{|l|}{ Male } & \multicolumn{2}{|l|}{ Female } & \multicolumn{2}{|l|}{ Both sexes } \\
\hline & New cases & Incidence & New cases & Incidence & New cases & Incidence \\
\hline $\begin{array}{l}1982 \\
1983 \\
1984\end{array}$ & $\begin{array}{l}0 \\
2 \\
3\end{array}$ & $2 \cdot 3(0 \cdot 7$ to $5 \cdot 4)$ & $\begin{array}{l}3 \\
0 \\
0\end{array}$ & $1.3(0.3$ to 3.9$)$ & $\begin{array}{l}3 \\
2 \\
3\end{array}$ & $1.8(0.8$ to 3.6$)$ \\
\hline $\begin{array}{l}1985 \\
1986 \\
1987 \\
1988\end{array}$ & $\begin{array}{l}4 \\
3 \\
6 \\
2\end{array}$ & $5 \cdot 0(2 \cdot 8$ to $8 \cdot 3)$ & $\begin{array}{l}5 \\
2 \\
3 \\
4\end{array}$ & $4 \cdot 5(2 \cdot 5$ to $7 \cdot 6)$ & $\begin{array}{l}9 \\
5 \\
9 \\
6\end{array}$ & $4 \cdot 8(3 \cdot 0$ to $6 \cdot 5)$ \\
\hline $\begin{array}{l}1989 \\
1990 \\
1991\end{array}$ & $\begin{array}{l}6 \\
5 \\
3\end{array}$ & $6 \cdot 0(3 \cdot 3$ to $10 \cdot 1)$ & $\begin{array}{l}2 \\
3 \\
5\end{array}$ & $4 \cdot 2(2 \cdot 0$ to $7 \cdot 7)$ & $\begin{array}{l}8 \\
8 \\
8\end{array}$ & $5 \cdot 1(3 \cdot 1$ to $7 \cdot 1)$ \\
\hline Total & 34 & $4 \cdot 6(3.0$ to $6 \cdot 1)$ & 27 & $3 \cdot 5(2 \cdot 2$ to $4 \cdot 8)$ & 61 & $4.0(3.0$ to 5.0$)$ \\
\hline
\end{tabular}


TABLE IV Incidence by urban-rural residence

\begin{tabular}{|c|c|c|c|c|c|c|c|}
\hline & \multirow{2}{*}{$\begin{array}{l}\text { Male } \\
(n=34)\end{array}$} & \multirow{2}{*}{$\begin{array}{l}\text { Female } \\
(n=27)\end{array}$} & \multirow{2}{*}{$\begin{array}{l}\text { Both sexes } \\
(n=6 I)\end{array}$} & \multicolumn{3}{|c|}{ Incidence $(100000 / y)^{\star}$} & \multirow{2}{*}{$\begin{array}{l}95 \% \text { Confidence } \\
\text { intervals }\end{array}$} \\
\hline & & & & Male & Female & Both sexes & \\
\hline $\begin{array}{l}\text { Urban } \\
\text { Semirural } \\
\text { Rural }\end{array}$ & $\begin{array}{c}22(21521) \\
3(5678) \\
9(45315)\end{array}$ & $\begin{array}{c}21(22988) \\
1(5135) \\
5(46502)\end{array}$ & $\begin{array}{r}43(44509) \\
4(10813) \\
14(91817)\end{array}$ & $\begin{array}{r}10 \cdot 2 \\
5 \cdot 3 \\
2 \cdot 1\end{array}$ & $\begin{array}{l}9 \cdot 1 \\
2 \cdot 0 \\
1 \cdot 1\end{array}$ & $\begin{array}{l}9 \cdot 6 \\
3 \cdot 7 \\
1 \cdot 5\end{array}$ & $\begin{array}{l}(6.7 \text { to } 1.3) \\
(1.0 \text { to } 9.5) \\
(0.8 \text { to } 2.6)\end{array}$ \\
\hline
\end{tabular}

^ Based on population distribution in Ioannina prefecture according to National Statistic Organisation, 1981 census (figures in brackets).

periods, respectively. There was a predominance of the patients from urban areas (Table IV). A third of all cases of UC had pancolitis while a quarter had only proctitis. More than one half were categorised as having moderate or severe disease.

Finally, the presence of the extraintestinal manifestations in our UC patients was recorded in $11 \cdot 5 \%$. In fact $4 / 52(7 \cdot 7 \%)$ had associated joint involvement and interestingly three of them (75\%) had sacroiliatis. In addition, one patient developed pericholangitis, while one patient with joint involvement had also chronic active hepatitis, proved by needle biopsy, without any detection of hepatitis B or C markers, or both and another one had chronic active hepatitis. In contrast, skin involvement has not been recorded in this group of our patients.

The mean annual incidence rate for $\mathrm{CD}$ was $0 \cdot 3 / 10^{5}$ inhabitants $(95 \%$ confidence intervals $0 \cdot 1$ to $0 \cdot 8 / 10^{5}$ ). The male to female ratio was 1.5 $(3 \cdot 2)$. Two of them $(40 \%)$ had extraintestinal manifestations (Table V).

\section{Discussion}

Our findings show that in this area of Greece Crohn's disease is still rare with one of the lowest incidences yet reported. In contrast ulcerative colitis is comparatively common with an incidence similar to that found in several other European countries.

Year of diagnosis and age distribution at the time of diagnosis $(n=61)$.
How valid are these findings? Could our results be the result of poor case ascertainment or bias in ascertainment and diagnosis? Although the results are based only on patients referred to our university clinic there are no other gastroenterologists working in the area, either in private practice or in the National Health Service. Referral of patients to other centres outside the area is difficult because of Ioannina's geographical isolation. The closest neighbouring academic centres are in Athens and Thessalonika; both are more than four hours away by car. Furthermore most general practitioners refer patients to our unit for endoscopy. Thus the likelihood of patients with inflammatory bowel disease being referred elsewhere or to other local specialists is low. It is possible that patients with mild disease are treated by their general practitioner alone or even do not seek medical attention. This might explain why most of our patients were categorised as having moderate or severe disease and why the proportion with proctitis alone $(25 \%)$ is lower than in some other studies. ${ }^{8}$ Nevertheless it is not plausible that lack of ascertainment would be sufficient to account for the enormous difference in incidence between the two diseases. Bias in diagnosis seems equally unlikely given the modern investigative techniques available. Patients with both diseases were fully investigated with most having both colonoscopy and small bowel radiology.

The frequency of gastrointestinal tuberculosis in Ioannina seems to be very low, as during the past 10 years we have encountered only two cases of proved gastrointestinal tuberculosis.

How does the incidence of inflammatory bowel disease in Ioannina compare with that reported from other areas of Greece and the rest of Europe? In the past both UC and CD were thought to be uncommon in Greece compared with northern Europe but no earlier studies have been reported. A preliminary report from Crete suggests that the incidence of UC $\left(5 \cdot 4 / 10^{5} / y\right.$ in $1990-91$ ) is similar to that in our area with CD being more common $(2 \cdot 5 / 10 / y$ in $1990-91) .{ }^{9}$ It may be significant that in the past 20 years there has been rapid development of tourism in Crete and the lifestyle of many Cretans is now comparatively Westernised compared with the lifestyle of residents of Ioannina.

Our incidence of ulcerative colitis is similar to that reported from several European countries but not as high as recent figures from Scandinavia. ${ }^{3510-16}$ The increased incidence of UC among our urban population has also been reported by others. ${ }^{517-20} \mathrm{It}$ is still unclear whether such urban-rural differences show true incidence differences or reflect easier access to hospital care and hence greater case ascertainment among urban populations. Our findings 
TABLE V Crohn's disease (CD) among Ioannina prefecture residents on 1 December 1991

\begin{tabular}{|c|c|c|c|c|c|c|c|c|}
\hline$S e x / D O B$ & $\begin{array}{l}\text { Year of } \\
\text { diagnosis }\end{array}$ & $\begin{array}{l}\text { Presented and } \\
\text { followed up by } \\
\text { us, or both }\end{array}$ & $\begin{array}{l}\text { Duration of } \\
\text { symptoms before } \\
\text { diagnosis }\end{array}$ & $\begin{array}{l}\text { Barium } \\
\text { enema }\end{array}$ & Enteroclysis & $\begin{array}{l}\text { Localisation } \\
\text { of disease }\end{array}$ & $\begin{array}{l}\text { Extraintestinal } \\
\text { manifestations }\end{array}$ & Histological findings \\
\hline M/1938 & 1984 & 1984 & 5 months & + & + & $\begin{array}{l}\text { Small and large } \\
\text { bowel }\end{array}$ & Sacroilietis & $\begin{array}{l}\text { Rectal biopsy showing } \\
\text { granuloma (rectum) }\end{array}$ \\
\hline$F / 1946$ & 1986 & 1986 & 10 years & + & - & Large bowel & $\begin{array}{l}\text { Pyoderma } \\
\text { Gangrenosum }\end{array}$ & Probable CD (colon) \\
\hline $\begin{array}{l}F / 1940 \\
M / 1951\end{array}$ & $\begin{array}{l}1990 \\
1990\end{array}$ & $\begin{array}{l}1990 \\
1990\end{array}$ & $\begin{array}{l}7 \text { years } \\
2 \text { months }\end{array}$ & $\overline{+}$ & $\begin{array}{l}+ \\
-\end{array}$ & $\begin{array}{l}\text { Small bowel } \\
\text { Large bowel }\end{array}$ & & $\begin{array}{l}\text { No histology } \\
\text { Interminate colitis } \\
\text { (colon) }\end{array}$ \\
\hline M/1948 & 1991 & 1991 & 30 years & \pm & ND & Small bowel & & $\begin{array}{l}\text { Probable } \mathrm{CD} \text { (small } \\
\text { bowel) }\end{array}$ \\
\hline
\end{tabular}

$\mathrm{ND}=$ not done

with regard to disease extent and severity are similar to those reported from Copenhagen and Rochester, Minnesota. ${ }^{21} 22$

An increasing incidence of Crohn's disease over the past 40 years has been reported from many Western countries. ${ }^{3223}$ In contrast the incidence in southern Europe was thought to be much lower but until recently good data were lacking. ${ }^{45}$ Recent studies from Italy and Spain show that Crohn's disease is not uncommon in these countries with an incidence about a half that reported from northern Europe. ${ }^{3522} 24$ It is not clear whether this reflects better case ascertainment or the emergence of Crohn's disease as it did in the more northern countries 30 years earlier.

Although within populations the incidence of $\mathrm{CD}$ is usually lower than the incidence of $\mathrm{UC}$, the incidence of (and death from) the two conditions across populations tends to run in parallel such as that in any country where Crohn's disease is common ulcerative colitis is also common. ${ }^{25}$ While there are a few areas where CD remains rare despite UC being common this correlation suggests that UC and CD have some environmental determinants in common. Such determinants are probably related to current Western diets and lifestyles. If this hypothesis is correct one might expect that in areas like Ioannina the incidence of $\mathrm{CD}$ will increase rapidly in the next 10 years. Prospective epidemiological studies in these areas should prove fruitful.

We wish to thank Mr G E Papanikolaou for excellent secretarial assistance.

1 Devlin HB, Datta D, Dellipiani AW. The incidence and prevalence of inflammatory bowel disease in North Tees Health District. World $\mathcal{F}$ Surg 1980; 4: 183-93.

2 Haug K, Schrumpf E, Barstad S, Fluge G, Halvorsen JF, and The Study Group of Inflammatory Bowel Disease in Western Norway. Epidemiology of ulcerative colitis in Western Norway. Scand F Gastroenterol 1988; 23: 517-22.
Binder V, Both H, Hansen PK, Hendriksen C, Kreiner S, Torp-Pedersen $\mathbf{K}$. Incidence and prevalence of ulcerative corp-Pedersen K. Incidence and prevalence of ulcerative colitis and Crohn's disease in the county of

4 Ochoa RV. Estudio epidemiologico en la enfermadad de Crohn en Galicia en el periodo de 1976 a 1983. Rev Esp Enferm Apar Dig 1984; 66: 273-9.
5 Lanfranchi GA, Michelini M, Brignola C, Campieri $M$, Cortini C, Martzio L. Uno studio epidemiologico sulle mallatie inflammatorie intestinali nella procincia di Bologna. mallatie inflammatorie intestinal

6 Truelove SC, Witts IJ. Cortisone in ulcerative colitis. Report on therapeutic trial. $B M \mathcal{F} 1953 ; 2: 375$.

7 Gardner MJ, Gardner SB, Winter PD. Confidence interval analysis (CIA). Microcomputer Program Manual Version 1.0 London: BMJ Publishing Group, 1989.

8 Singleton WJ. Clinical features, course and laboratory findings of in ulcerative colitis. Kirsner BJ, Shorter GR eds. In: Inflammatory bowel disease. Third ed. Philadelphia: Lea and Febiger 1988: 167-74.

9 Manousos ON, Giannadaki E, Koutroubakis J, et al. Inflammatory bowel disease (IBD) in Greece. Incidence and prevalence in Heraklion, Crete. Hellenic fournal of Gastro prevalence in Heraklion, Cre

10 Evans JG, Acheson EP. An epidemiological study of ulcerative colitis and regional enteritis in Oxford area. Gut 1965; 6: $\vec{c}$ 311-24.

11 Lennard-Jones JE. Regional enteritis (Crohn's disease): definition and diagnoses. Stockholm: Skandia Internationa Symposia: regional enteritis 1970: 109 .

12 Colombel JF, Salomez JL, Cortot A, et al. Incidence of inflammatory bowel disease in Northwestern France. Scand 7 Gastroenterol 1989; 24 (suppl 170): 22-4.

13 Vucelic B, Korac B, Sentic M, et al. Ulcerative colitis in Zagreb, Yugoslavia: incidence and prevalence 1980-1989. Int $\mathcal{F}$ Epidemiol 1991; 20: 1043-7.

14 Bitter J, Hulec J. Ulcerozni kolitida v severoceskem kraji. Cesk Gastroenterol 1980; 34: 137-44.

15 Yavorska N, Djadjova-Boneva M. Epidemiological study of ulcerative colitis in Bulgaria. Scand $\mathcal{f}$ Gastroenterol 1982; 17 (suppl 78): 282

16 Shivananda S, Mayberry JF, Pena AS. Epidemiology of proctocolitis in Regio, Leiden, The Netherlands - a population study from 1979-83. Scand $\mathcal{F}$ Gastroenterol 1987; 12: 993-1002.

17 Sinclair ST, Brunt WP, Mowat NAG. Nonspecific proctocolitis in Northeastern Scotland: a community study. Gastroenterology 1983; 85: 1-11.

18 Monk M, Mendeloff AI, Siegel CI, Lilenfeld A. An epidemiological study of ulcerative colitis and regional enteritis mong adults in Baltimore. Social and demographic factors. anong adults in Baltim5: 5077-57.

Gastroenterology 1969; 56: 847-57. Epidemiologi aspekte 을
19 Brandes JW, Lorenz-Meyer K. Epidemiolo zur enterocolitis regionalis Crohn and colitis ulcerosa in Marburg/Lahn (FRG). Zeischen 1962 und 1975. Z Gastro- O enterol 1983; $21: 69-78$

20 Linden G. Ulcerative colitis in Finland. One year incidence in $N$ all hospital. Dis Colon Rectum 1971; 14: 264-6.

21 Stonnington CM, Phillips SF, Melton LJ, Zinsmeister AR. W Chronic ulcerative colitis: incidence and prevalence in a $O$ community. Gut 1987; 28: 402-9.

22 Both H, Torp-Pedersen K, Kreiner S, Hendriksen C, Binder $\mathrm{V}$. Clinical appearance at diagnosis of ulcerative colitis and Crohn's disease in a regional patient group. Scand 7 Gastroenterol 1983; 18: 987-91.

23 Mendeloff AI, Calkins BM. The epidemiology of idiopathic inflammatory bowel disease. Kirser BJ, Sh of idiopathic inter Third ed. Philadelphia: Lea and Febiger 1988: 3-34.

24 Martinez G, Fernandez Y, Saez LR, Martinez E. Estudio epidemiologico de la enfermadad de Crohn en la region Asturiana. Rev Esp Enferm Apar Dig 1983; 63: 534-41.

25 Sonnenberg A. Geographic variation in the incidence of and mortality from inflammatory bowel disease. Dis Colon Rectum 1986; 29: 854-61. 